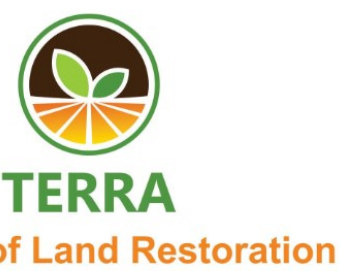

\title{
The Growth and Production of Three Sweet Potato Varieties as Affected by Dosage of Potassium Fertlizer on the Ultisols of Bengkulu Province
}

\author{
Taufiq Al-Qodri ${ }^{1}$, Bambang Gonggo Murcitro ${ }^{2 *}$, Alnopri ${ }^{1}$, Prasetyo ${ }^{1}$ \\ ${ }^{1}$ Agroecotechnology Department, University of Bengkulu \\ ${ }^{2}$ Soil Science Department, University of Bengkulu (Corresponding author) \\ e-mail: bgonggo@unib.ac.id
}

\begin{abstract}
This study aims to study the interaction between varieties and the correct dose of potassium fertilizer, determine the right dose of potassium fertilizer and the appropriate variety of sweet potato in Ultisol. In this study, the research design used was a completely randomized block design (RAKL) with two (2) factors with three replications. The first factor is three varieties of sweet potato, namely Cilembu, Atin 3, and Beta 1. The second factor is the dose of KCl fertilizer which consists of 4 levels of dosage, namely $0 \mathrm{~kg} \mathrm{ha} a^{-1}, 150 \mathrm{~kg} \mathrm{ha}^{-1}, 300 \mathrm{~kg} \mathrm{ha}^{-1}$, and $450 \mathrm{~kg} \mathrm{ha}{ }^{-1} \mathrm{KCl}$ fertilizer. The results showed no significant interaction between the dose of KCl fertilizer and the three varieties of sweet potato. The Antin 3 variety produced the most extended tendril length compared to the other two varieties. The lowest number of branches was produced by Beta 1 variety. The Cilembu variety produced the most significant tuber weight per plot and estimated weight per plot. The Cilembu variety is proven to have the highest level of sweetness.
\end{abstract}

Keywords: sweet potato, potassium fertilizer, Ultisol Bengkulu

\section{INTRODUCTION}

Sweet potatoes (Ipomea batatas L.) are a type of plant whose food storage rate is found in tubers. Sweet potato plants are thought to have originated in the Central American region that spread throughout the world. The spread of sweet potatoes to Asia was carried out by Spanish people in the 16th century who entered various countries with tropical climates such as the Philippines, Japan, and Indonesia (Purwono \& Purnawati, 2007). Sweet potatoes are one of the foodstuffs that are quite in demand in Indonesia, in addition to significant staples such as rice. Sweet potatoes can be used in various processed that people in Indonesia quite prefer as secondary food ingredients (Antia et al., 2006). The chemical components contained in sweet potatoes are composed mostly of water $72.8 \%$ and carbohydrates $24.2 \%$, and other contents such as fats, proteins, minerals, and vitamins significantly affect the planting activities and genetics of sweet potatoes (Richana, 2012). Sweet potatoes (Ipomea batatas L.) are a type of plant whose food storage rate is found in tubers. Sweet potato plants are thought to have originated in the Central
American region that spread throughout the world. The spread of sweet potatoes to Asia was carried out by Spanish people in the 16th century who entered various countries with tropical climates such as the Philippines, Japan, and Indonesia (Purwono \& Purnawati, 2007). Sweet potatoes are one of the foodstuffs that are quite in demand in Indonesia, in addition to major staples such as rice. Sweet potatoes can be used in various processed that are quite preferred by people in Indonesia as secondary food ingredients (Antia et al., 2006). The chemical components in sweet potatoes are composed chiefly of water $72.8 \%$ and carbohydrates $24.2 \%$, and other contents such as fats, proteins, minerals, and vitamins significantly affect the planting activities and genetics of sweet potatoes (Richana, 2012).

Indonesia is the fifth largest sweet potatoproducing country in the world (BPS, 2016). Data shows sweet potato production in 2014 reached 2,382,658 tons and in 2015 decreased to 2,297,634 tons. Sweet potatoes in Indonesia are used as food as much as $89 \%$, with the average level of consumption ranging from $7.9 \mathrm{~kg} / \mathrm{capita} /$ year with demand varying in the fulfillment of their needs. 
Food diversification, including sweet potatoes, needs to be developed because it is considered necessary. The need for sweet potatoes as food and the industrial field is increasing, and increased sweet potato production. The decrease in the production of sweet potatoes is suspected because the area of planting of land used in the cultivation of sweet potatoes used is decreasing, and the transfer of land functions that occur in various regions to the sweet potato commodity itself.

Ultisol land has enormous potential as a strategic choice for agricultural development to compensate for the narrowing of fertile land that is decreasing and can be one of the solutions for agricultural development that takes place because there is still many lands that have not been entirely used in the territory of Indonesia (Subowo, 2012). Ultisol has a yellow-red soil color. Its aggregates are unstable, soil porosity and water holding capacity are very low, $\mathrm{pH}$ is low, and nutrient content is low. Ultisol also has few micro and macro-organisms of both its type and abundance. The utilization of marginal land such as Ultisol needs to be managed quality and health both from physical, chemical, and biological aspects.

Fertilization is one of the efforts in increasing the production of sweet potato plants. Sweet potato plants require elements $\mathrm{N}, \mathrm{P}$, and $\mathrm{K}$ in the formation of bulbs. Potassium (K) nutrients can increase the formation of sugar substances in sweet potato plant tubers, increase flower formation as well as chlorophyll, increase water absorption, increase the strength of plant leaves, increase carbohydrate formation, increase leaf enlargement and increase resistance to disease (Juanda \& Cahyono, 2000). The primary role of nutrient $\mathrm{K}$ in plants is as an activator of various types of enzymes. The $\mathrm{K}$ element available in the soil causes plants to fall resistant, stimulate root growth, and plants are more resistant to pest and disease attacks. The use of $\mathrm{K}$ fertilizer at doses of $300 \mathrm{~kg} / \mathrm{ha}$ affects the growth and yield of sweet potato plants (Hakim et al., 2018). According to Lestari (2009), K fertilizer can increase the yield of sweet potato plants and increase the dose given. Sweet potato production results can be increased by fertilizing correctly and well with the level of composition and implementation of its giving (Djalil, 2004).

The use of superior varieties is one of the accessible and appropriate technologies to increase crop yields (Balitkabi, 2012). Varieties of sweet potatoes include Cilembu, Beta 1, and Antin 3, released by Balitkabi. The selection of varieties used is based on the planting area and the taste of sweet potatoes. The sweet potato plant is a plant that can grow on marginal soils such as Ultisol Bengkulu.

\section{MATERIALS AND METHODS}

This research has been carried out from January 2020 to May 2020 in Beringin Raya Village, Muara Bangkahulu District, Bengkulu City. The experimental design used is a randomized complete block design (RCBD) factorial with two factors. The first factor is the variety consisting of three (3) varieties. The second factor is the dose of potassium fertilizer consisting of four (4) dose levels that are $0 \mathrm{~kg} \mathrm{ha}^{-1}, 150 \mathrm{~kg} \mathrm{ha}^{-1}, 300 \mathrm{~kg} \mathrm{ha}^{-1}$, and $450 \mathrm{~kg} \mathrm{ha}^{-1}$ fertilizer $\mathrm{KCl}$. Sweet potato plants planted on a map measuring $3 \mathrm{~m} \times 2 \mathrm{~m}$ each mapped has a planting distance of $75 \mathrm{~cm} \times 50 \mathrm{~cm}$. Overall the area of land used is $36 \mathrm{~m} \mathrm{x} 12 \mathrm{~m}$.

The data obtained were analyzed using Analysis of Variance (ANAVA), with a test level of 5\%. Real different data will be conducted an average comparison test (LSD) for varieties. The effect of the treatment of potassium fertilizer obtained is analyzed by orthogonal polynomial method to get the correct dose in the soil of Ultisol. Particular data of the level of sweetness is presented in a description.

\section{RESULT AND DISCUSSION}

The results of the variant analysis showed that there were noticeable differences between varieties to the variables observed in this study, as seen in plant tendril length variables, the number of plant branches, weight/plot, and level of sweetness. As for the treatment of potassium fertilizer, doses and interactions exert an unreal influence on all observed variables (Table 1).

The diameter of bulbs formed differs in real between varieties. The research results conducted by Erita et al. (2012) showed that each genotype could adapt to the environment. These genetic differences can affect the growth and yield, and adaptability of a variety grown in an environment.

Fresh bulb weight shows that there is no noticeable difference in the three varieties of sweet potatoes. This is in line with the results of research from Lakitan (2007) that external factors affect the growth and yield of sweet potato plants. Sweet potato plants always grow new shoots from their growth and old leaves and branches that make fresh bulb weight difficult to accumulate (Hakim et al., 2018). The Atin 3 variety had the longest significant plant length tendrils compared to Beta 1 and Cilembu. Welsh (2005) states that an area generally has the same environmental conditions, but the differences in phenotypes respond to the surrounding environment differently. 
Table 1. Results of variance analysis of observed variables

\begin{tabular}{lllcll}
\hline \multirow{2}{*}{ No } & & \multicolumn{3}{c}{ F-calc } & \\
\cline { 2 - 4 } & Variable & Variety & $\begin{array}{c}\text { Dose } \\
\text { Potassium }\end{array}$ & Interaction & CV (\%) \\
\hline 1. & Tendril length & $35.50^{*}$ & $0.49 \mathrm{~ns}$ & $0.34 \mathrm{~ns}$ & 25.82 \\
2. & Number of branches & $6.52^{*}$ & $2.51 \mathrm{~ns}$ & $1.83 \mathrm{~ns}$ & 19.61 \\
3. & Diameter of bulbs & $0.30 \mathrm{~ns}$ & $1.20 \mathrm{~ns}$ & $1.89 \mathrm{~ns}$ & 20.78 \\
4. & Fresh bulb weight & $1.21 \mathrm{~ns}$ & $0.48 \mathrm{~ns}$ & $0.58 \mathrm{~ns}$ & 48.25 \\
5. & Bulb/sample weight & $6.98 *$ & $0.48 \mathrm{~ns}$ & $0.55 \mathrm{~ns}$ & 47.28 \\
6. & $\begin{array}{l}\text { Estimated weight of } \\
\text { bulbs/tiles }\end{array}$ & $6.97 *$ & $0.48 \mathrm{~ns}$ & $1.27 \mathrm{~ns}$ & 47.22 \\
\hline
\end{tabular}

* significant at $5 \%$ level $(\mathrm{P} \leq 0.050)$; ns non significant $(\mathrm{P}>0.050)$

On average, it can be seen that Beta varieties have lower growth and yields (Table 2). According to Erita et al. (2012), each genotype can adapt to the environment. These genetic differences can affect the growth and yield as well as the adaptability of a planted variety.

The heaviest bulb/sample weight was produced by the Cilembu variety ( $376.08 \mathrm{~g})$, which was significantly different from Atin 3 and Beta 1 . The bulb weight of sweet potato was influenced by the environment in which it was planted and the nutrients absorbed. The research results Hakim et al. (2018) showed that the dose of potassium fertilizer would have a significant effect on the yield of tubers formed.

The estimated weight of bulbs formed in this study showed the best value for the Cilembu variety (6019.8a), which was significantly different from the Antin 3 variety (3525.9 g) and the Beta 1 variety (3091 g). The environment is an external factor that drives the yield of cultivated plants (Pigllucci, 1996).

The level of sweetness obtained by each variety with an average of 14.75 Brix in the Cilembu variety, Antin 3 variety of 11.75 Brix, and Beta 1 of 11.20 Brix (Figure 1). Description of Balitkabi (2012) indicates that the Cilembu variety is a sweet potato variety with a sweet taste.

$\mathrm{KCl}$ fertilizer is an inorganic fertilizer that plays a role in the growth and yield of each plant. The content of $\mathrm{K}$ elements contained in $\mathrm{KCl}$ fertilizer can help in the process of carbohydrate accumulation, transport of carbohydrates, assist in the process of working enzymes in plants, and can improve the quality of crop yields. The application of potassium fertilizer can affect the quality of sweet potato plants (Garfansa et al., 2021). Plants lack element K resulting in the growth of plants into dwarfs, leaves look dry and burned on the sides, inhibit the formation of charcoal hydrates on seeds, the surface of the leaves show uneven symptoms of chlorotic, the appearance of brown patches similar to symptoms of the disease on the dark green part. While excess potassium can cause the leaves to age quickly, the mg content of the leaves can decrease, so that the activity of photosynthetic is disrupted (Paulus, 2006).

The application of $\mathrm{KCl}$ in sweet potato plants in this study had an insignificant effect on all observed variables. The results of the initial soil analysis showed that the $\mathrm{K}$ content in the soil was 0.26 me/100 g, which was relatively low, and the soil $\mathrm{pH}$ was 4.36. This means that the soil used in this study is a type of soil that is less fertile and acidic.

This is thought to be one of the factors that make the treatment of $\mathrm{K}$ fertilizer not significantly affect sweet potato plants because the nutrients provided have resulted in an excess effect (luxury consumption). The level of $\mathrm{K}$ fertilizer given is significant for each dose. As shown by the research results by Amisnaipa et al. (2009), the application of $\mathrm{K}$ fertilizer at low to moderate nutrient status showed a significant increase in plant length, while $\mathrm{K}$ fertilizer with high nutrient status did not show an increase in plant length. This is thought to make the plant not respond to the treatment given (Astuti, 2010).

The external factor that is suspected to be one of the causes of the ineffectiveness of $\mathrm{KCl}$ treatment given to sweet potato plants is the occurrence of leaching on the soil caused by continuous rain during the study. The loss of $\mathrm{K}$ element that occurs does not significantly affect the application of $\mathrm{KCl}$ fertilizer. The research results conducted by Musnamar (2003) indicate that loss of nutrients can occur due to evaporation, absorption, and leaching of nitrate compounds by 
continuous rain, which makes the initially available nutrients little or none at all. According to Haris \& Krestini (2009), element $\mathrm{K}$ is a nutrient that moves and is sensitive to the washing process, especially in the tropics with high rainfall.

The physical properties of ultisol, which have a clayey texture with high water-holding properties, make sweet potato plants disrupted in tuber growth. Sweet potato plants grow well in soil that has good drainage and aeration. Although intensive soil management efforts have been carried out on the land used, it still does not affect the growth and yield of sweet potato plants in the ongoing research.

The altitude, which is classified as low, which results in high rainfall conditions, makes the application of $\mathrm{K}$ fertilizer not optimally translocated to sweet potato tubers. Humidity affects the rate of transpiration in plants (Lakitan, 2007). An environment with high air humidity affects the diffusion of water in the air space, on growth will take place slowly. If, on the contrary, the humidity in conditions around plants is low, then the diffusion of water in the air space on growth takes place quickly.

The height of the study site in the lowlands is suspected to be one of the external factors that make the treatment of $\mathrm{K}$ fertilizer application not significantly affect the growth and yield of sweet potato plants. The altitude factor is one factor that influences plant growth because it is not the same as the place where the plant is located and makes each variety tested perform different adaptability. This is by Pigllucci (1996) statement that the unequal environment in areas on the earth's surface causes plants to develop different adaptation mechanisms.

Tabel 2. Average growth and production of three sweet potato varieties

\begin{tabular}{|c|c|c|c|c|}
\hline Varieties & Tendril lenght $(\mathrm{cm})$ & Number of branches & $\begin{array}{c}\text { Bulb/sample } \\
\text { weight (g) }\end{array}$ & $\begin{array}{c}\text { Estimated } \\
\text { weight of } \\
\text { bulbs/tiles(g) }\end{array}$ \\
\hline Cilembu & $97.19 \mathrm{~b}$ & $24.55 \mathrm{a}$ & $376.08 \mathrm{a}$ & $6019.8 \mathrm{a}$ \\
\hline Atin 3 & $217.41 \mathrm{a}$ & $22.72 \mathrm{a}$ & $220.05 b$ & $3525.9 \mathrm{~b}$ \\
\hline Beta 1 & $118.55 \mathrm{~b}$ & $18.38 \mathrm{~b}$ & $192.87 \mathrm{~b}$ & $3091 b$ \\
\hline
\end{tabular}

Numbers followed by the same lowercase letter in the same column is not significantly different at the $5 \%$ LSD level

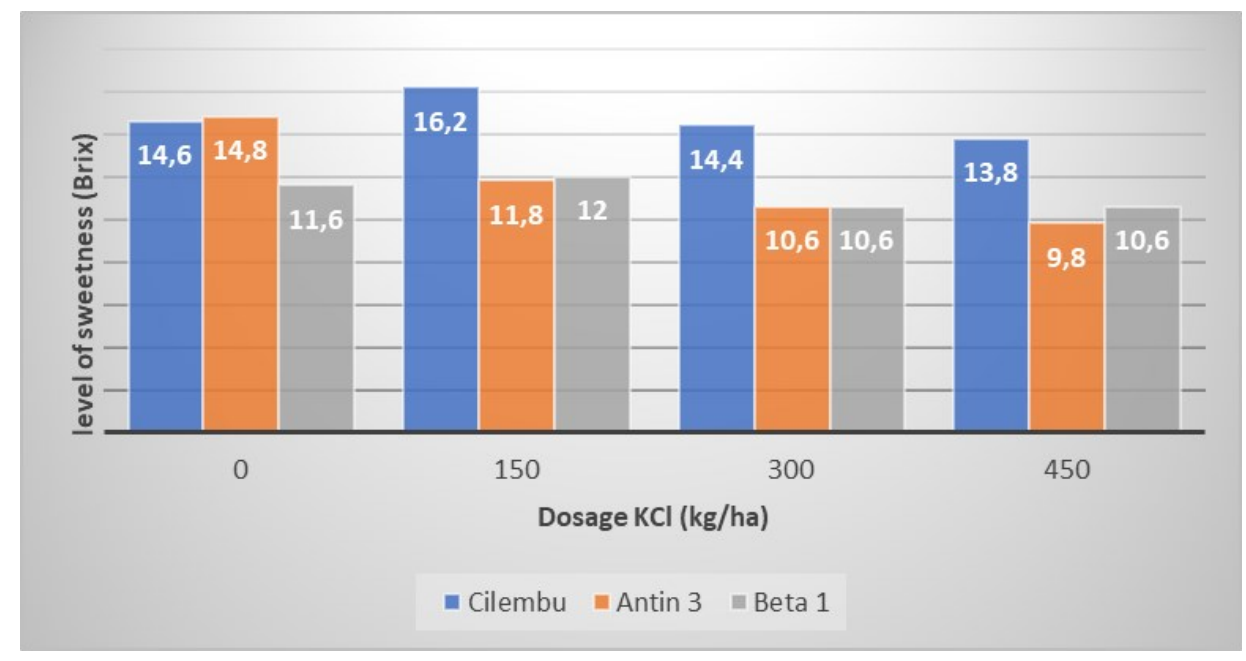

Figure 1. Histogram of sweetness levels of three varieties of sweet potato at different dose levels 


\section{CONCLUSION}

There was no real interaction between $\mathrm{KCl}$ fertilizer and the three varieties of sweet potatoes in the study conducted. The Antin 3 sweet potato variety showed the highest growth seen from the highest tendril length growth compared to the other two varieties. The Beta 1 variety produces the growth of the smallest number of branches. The Cilembu variety produces the bulb/sample weight and the highest estimated weight of bulbs/tiles and the sweetest flavors.

\section{References}

Aminsnaipa, Susila, A.D., Situmorang, R. \& Purnomo, D.W. (2009). Penentuan kebutuhan pupuk kalium untuk budidaya tomat menggunakan irigasi tetes dan mulsa poliethylene. J. Agron. Indonesia, 37(2), 115-122.

Antia, B., Akpan, E.J., Okon, P.A. \& Umoren, I.U. (2006). Nutritive and anti-nutritive evaluation of sweet potatoes (Ipomoea batatas) Leaves. Pakistan Journal of Nutrition. 5(2), 166-168. DOI: 10.3923/pjn.2006.166.168.

Astuti, L. T. W. (2010). Pertumbuhan, Produksi dan Kualitas Beberapa Varietas Ubi Jalar (Ipomea batatas, L) pada Aplikasi Kompos dan Pupuk KCl. Tesis. Fakultas Pertanian. Universitas Sumatra Utara, Medan.

Badan Pusat Statistik (BPS). (2016). Produksi Ubi Jalar Menurut Provinsi. http://www.bps.go.id. 9 September 2019.

Balitkabi. (2012).Deskripsi Varietas Unggul KacangKacangan dan Umbi-Umbian. Balai Penelitian Tanaman Aneka Kacang dan Umbi, Malang.

Djalil, M., Jahja, D. \& Pardiansyah. (2004). Pertumbuhan dan hasil tanaman ubi jalar (Ipomoea batatas L.) pada pemberian beberapa takaran abu jerami padi. Stigma, 12(2), 193-194.

Erita, H., Mahmud, T. \& Fazil, R. (2012). Pengaruh jenis pupuk organik dan varietas terhadap pertumbuhan dan hasil tanaman cabai (Capsicum annum L.). Jurnal Floratek, 7, 173-178.
Garfansa, M.P., Sudiarso \& Suminarti, M.E. (2021). Pengaruh pemberian pupuk kalium terhadap kualitas dua varietas ubi jalar (Ipomoea batatas L.). Agro Bali: Agricultural Journal, 4(2), 170176. DOI: $10.37637 / a b . v 4 i 2.692$.

Hakim, A., Soelaksini, L. \& Muqwin, R.A. (2018). Suplai dosis $\mathrm{P}$ dan K terhadap laju pertumbuhan dan produksi tanaman ubi jalar (Ipomea batatas, L.) Varietas Antin 3. Agriprima, Journal of Applied Agricultural Sciences, 2, 49-53. DOI: 10.25047/ agriprima.v2i1.78.

Haris, A. S. \& Krestiani, V. (2009). Studi Pemupukan Kalium Terhadap Pertumbuhan dan Hasil Jagung Manis (Zea mays saccharata sturt) Varietas Super Bee. Fakultas Pertanian. Universitas Muria Kudus, Kudus.

Juanda \& Cahyono, B.(2000). Ubi jalar : Budidaya dan Usaha Taninya. Kanisius, Yogyakarta.

Lakitan, B. (2007). Dasar-dasar Fisiologi Tumbuhan. Raja GrafindoPersada, Jakarta.

Lestari,A. P. (2009). Pengembangan pertanian berkelanjutan melalui subtitusi pupuk anorganik dengan pupuk organik. J. Agronomi, 13(1), 38-44.

Musnamar, E. I. (2003). Pupuk Organik Padat : Pembuatan dan Aplikasi. Penebar Swadaya, Jakarta.

Paulus, J.M.. (2006). Peranan kalium terhadap kualitas ubi beberapa varietas ubi jalar (Ipomoea batatas (L.) Lam.). Eugenia, 12(2),76-85.

Pigllucci, M. (1996). How organism respon to environmental change: from phenotypes to molecule (and vice versa). Trends in Ecology \& Evolution. 11 (4), 168-173. DOI: https://doi.org/10.1016/ 0169-5347(96)10008-2.

Purwono, L. \& Purnawati. (2007). Budidaya Tanaman Pangan. Agromedia, Jakarta.

Richana. (2012). Ubi Kayu dan Ubi Jalar. Nuansa, Bogor.

Subowo, G. (2012). Pemberdayaan sumberdaya hayati tanah untuk rehabilitasi tanah Ultisol terdegradasi. Jurnal Sumberdaya Lahan, 6(2), $79-88$.

Welsh, J. R. (2005). Fundamentals of Plant Genetics and Breeding. John Wiley and Sons, New York. 